
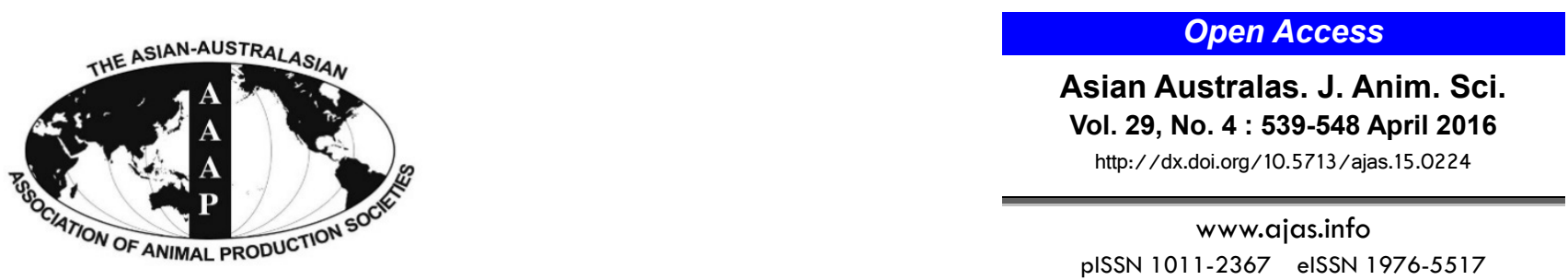

\title{
Influence of Palm Kernel Meal Inclusion and Exogenous Enzyme Supplementation on Growth Performance, Energy Utilization, and Nutrient Digestibility in Young Broilers
}

\author{
M. R. Abdollahi*, B. J. Hosking ${ }^{1}$, D. Ning ${ }^{1}$, and V. Ravindran \\ Institute of Veterinary, Animal and Biomedical Sciences, Massey University, Palmerston North 4442, New Zealand
}

\begin{abstract}
The objective of the present study was to investigate the influence of palm kernel meal (PKM) inclusion and exogenous enzyme supplementation on growth performance, nitrogen-corrected apparent metabolizable energy (AMEn), coefficient of apparent ileal digestibility (CAID) and total tract retention of nutrients in young broilers fed corn-based diets. Four inclusion levels of PKM (no PKM [PKM0], 8\% [PKM8], 16\% [PKM16], and 24\% [PKM24]) and two enzyme additions were evaluated in a $4 \times 2$ factorial arrangement of treatments. A total of 384, one-d-old male broilers (Ross 308 ) were individually weighed and allocated to 48 cages (eight broilers/cage), and cages were randomly assigned to eight dietary treatments. Results indicated that the inclusion of $8 \%$ and $16 \%$ PKM increased $(\mathrm{p}<0.05)$ the weight gain compared to the PKM0 diet. Birds fed the PKM8 diets had the highest $(\mathrm{p}<0.05)$ feed intake. Weight gain and feed intake were severely reduced $(\mathrm{p}<0.05)$ by feeding the PKM24 diet. Enzyme supplementation increased weight gain $(\mathrm{p}<0.05)$, independent of PKM inclusion level. In PKM0 and PKM8 diets, enzyme addition significantly $(\mathrm{p}<0.05)$ lowered feed conversion ratio (FCR); whereas enzyme addition had no effect on FCR of birds fed PKM16 and PKM24 diets. In PKM0 and PKM16 diets, enzyme addition significantly $(p<0.05)$ increased CAID of nitrogen and energy but had no effect in the PKM8 and PKM24 diets. Inclusion of PKM into the basal diet, irrespective of inclusion level, enhanced $(\mathrm{p}<0.05)$ starch and fat digestibility. Inclusion of PKM at $16 \%$ and $24 \%$ resulted in similar CAID of neutral detergent fiber (NDF) but higher $(\mathrm{p}<0.05)$ than that of the PKM0 and PKM8 diets. Enzyme addition, regardless of the level of PKM inclusion, significantly $(\mathrm{p}<0.05)$ increased CAID of NDF. There was a significant $(\mathrm{p}<0.05)$ decrease in AMEn with PKM inclusion of $24 \%$. The present data suggest that inclusion of PKM in broiler diets could be optimized if PKM-containing diets are formulated based on digestible amino acid contents and supplemented with exogenous enzymes. If amino acid digestibility and AME of PKM considered in the formulation, it can be included in broiler diets up to $16 \%$ with no deleterious effects on growth performance. (Key Words: Palm Kernel Meal, Exogenous Enzyme, Broiler, Performance, Nutrient Utilization)
\end{abstract}

\section{INTRODUCTION}

High demand for conventional feed ingredients due to competition with humans and other livestock species for feed resources and ever-increasing cost of these ingredients have motivated poultry nutritionists to maximize the use of locally available by-products. Palm kernel meal (PKM), an agro-industrial by-product, is a locally available and

\footnotetext{
* Corresponding Author: M. R. Abdollahi. Tel: +64-6-951-8255, Fax: +64-6-350-5684, E-mail: M.Abdollahi@massey.ac.nz ${ }^{1}$ AsiaPac Biotechnology Co. Ltd., Dongguan City, Guangdong 523808, China.

Submitted Mar. 17, 2015; Revised Jun. 8, 2015; Accepted Jul. 30, 2015
}

relatively inexpensive feedstuff in many tropical countries (Perez et al., 2000). Palm kernel meal is produced by extracting the oil from palm kernels using solvent extraction. Palm kernel oil might also be mechanically expelled and the coproduct is referred to as palm kernel cake (PKC; Sundu et al., 2006). Incorporation of PKM in broiler diets is limited and reported to be associated with impaired performance parameters (Mardhati et al., 2011). The deteriorated growth responses has been attributed to high fiber content, grittiness (Sundu et al., 2005; 2006) and low concentration of indispensable amino acids (AA) (Abdollahi et al., 2015).

Published data on the effect of PKM on growth 
performance of broiler chickens have been contradictory. Panigrahi and Powell (1991) reported that if supplemented with methionine and lysine, PKM can be included in broiler diets up to $40 \%$. Ezieshi and Olomu (2008) replaced $50 \%$ of corn in the broiler diet with PKM (30\% and 32.5\% PKM in starter and finisher diets, respectively) and reported lower body weight and a deteriorated feed conversion ratio (FCR). Shakila et al. (2012) reported that PKM up to $10 \%$, with or without enzyme, might be used in broiler diets without negatively affecting the performance.

Palm kernel meal contains high level of fiber with nonstarch polysaccharides (NSP) and $\beta$-mannan as the main fiber components of PKM. Almaguer et al. (2014) reported concentrations of 494 and $779 \mathrm{~g} / \mathrm{kg}$ of acid detergent fiber and neutral detergent fiber (NDF) in PKM. Knudsen (1997) reported values of 466 and $136 \mathrm{~g} / \mathrm{kg}$ for NSP and lignin in PKM, respectively. Abdollahi et al. (2015) reported that almost $96 \%$ of total NSP in PKM being in the form of insoluble NSP. Beta-mannans, also known as $\beta$ galactomannans, are linear polysaccharides with repeating units of $\beta-1-4$ mannose and side attachments of $\alpha-1-6$ glucose and/or galactose and commonly found in many feed ingredients (Knudsen, 1997; Jackson et al., 2004). Hsiao et al. (2006) reported $\beta$-mannan concentration of 12.6 and $16.1 \mathrm{~g} / \mathrm{kg}$ in dehulled and non-dehulled soybean meal samples, respectively. Mannans in PKM are hard, highlyinsoluble crystalline polymers of mannose and constitute the storage polysaccharides of the endosperm of palms (Daud and Jarvis, 1992). According to Dusterhoft et al. (1991), $78 \%$ of the total NSP in PKM is linear mannan. Jackson (2010) reported that PKM has a $\beta$-mannan content of 300 to $350 \mathrm{~g} / \mathrm{kg}$. Mannans are not depolymerised in the digestive tract of the birds due to the lack of mannandegrading enzymes.

Poultry are not able to degrade NSP due to lack of endogenous fiber-degrading enzymes and therefore feeding high fiber ingredients such as PKM might impair growth responses. Fiber in PKM has been found to have a complex structure consisting mannans (glucomannan and galactomannan) as the main component, cellulose, glucoronoxylans and arabinoxylans (Dusterhoft et al., 1991; Knudsen, 1997). Due to its complexity, fiber of PKM may benefit more from a combination of enzymes including $\beta$ mannanase, xylanase, cellulose, glucosidase and galactosidase. However, studies investigating the effect of enzyme on PKM-containing broiler diets are limited (Soltan, 2009; Shakila et al., 2012). This study sought to investigate the efficacy of an enzyme cocktail in corn-soybean mealbased broiler diets with graded levels of PKM. The objective of the current study was to examine the effects of four dietary inclusion levels of PKM, each without and with enzyme supplementation, on growth performance, nutrient digestibility and energy utilization of young broilers.

\section{MATERIALS AND METHODS}

\section{Enzyme}

The enzyme was supplied by AsiaPac (Dongguan) Biotechnology Co. Ltd, Guangdong, China, and was a cocktail of $\beta$-mannanase and NSP-degrading enzymes (Pokazyme PK516; including: $\beta$-mannanase, xylanase, amylase, protease, cellulase and $\beta$-glucanase). The enzyme was in powder form and added at the level recommended by the manufacturer $(200 \mathrm{~g} / \mathrm{t}$ of feed $)$.

\section{Diets}

The experimental design was a $4 \times 2$ factorial arrangement of treatments, which included four different levels of PKM inclusion $(0 \%, 8 \%, 16 \%$, and $24 \%)$ and two enzyme supplementations (without/with enzyme). Whole corn was obtained from a commercial supplier, and ground in a hammer mill (Bisley's Farm Machinery, Auckland, New Zealand) to pass through a screen size of $4.0 \mathrm{~mm}$. Broiler starter diets, based on corn, soybean meal and PKM, were formulated to meet the Ross 308 strain recommendations for major nutrients (Ross, 2007) and to be equivalent in respect of energy density, and digestible protein and $\mathrm{AA}$, calcium and available phosphorus concentrations. Palm kernel meal used in the current study had previously been analysed for nutrients, apparent metabolizable energy (AME) and ileal AA digestibility (Abdollahi et al., 2015) and the data were used to formulate the experimental diets. Four diets were formulated to contain no PKM (PKM0), 8\% (PKM8), 16\% (PKM16), and 24\% (PKM24) PKM (Table 1) and used to develop eight dietary treatments without and with the addition of enzyme. The diets contained $0.3 \%$ of titanium dioxide $\left(\mathrm{TiO}_{2}\right.$, Merck $\mathrm{KGaA}$, Darmstadt, Germany) as an indigestible marker for the determination of ileal nutrient digestibility. Diets were mixed in a single-screw paddle mixer (Bonser Engineering Co. Pty. Ltd., Merrylands, Australia). Following mixing, all diets were steam-conditioned at $70^{\circ} \mathrm{C}$ and pelleted using a pellet mill (Model Orbit 15; Richard Sizer Ltd., Kingstonupon-Hull, UK) capable of manufacturing $180 \mathrm{~kg}$ of feed/h and equipped with a die ring with 3-mm holes and $35-\mathrm{mm}$ thickness. Conditioning time of the mash was $30 \mathrm{~s}$ and the conditioning temperature was measured at the outlet of the conditioner. The diets were run in sequence with no change in the feeder rate, rotation speed or number of knives. Representative samples of all diets were collected after pelleting for chemical analysis.

\section{Birds and housing}

Experimental procedures were approved by the Massey University Animal Ethics Committee and complied with the 
Table 1. Composition and calculated analysis (\%, as fed) of the experimental diets

\begin{tabular}{|c|c|c|c|c|}
\hline \multirow{2}{*}{ Item } & \multicolumn{4}{|c|}{ Palm kernel meal (PKM) inclusion } \\
\hline & No PKM & $8 \%$ & $16 \%$ & $24 \%$ \\
\hline Corn & 55.10 & 51.39 & 42.55 & 33.68 \\
\hline Soybean meal, $48 \%$ & 31.06 & 26.05 & 20.89 & 15.60 \\
\hline Wheat bran & 4.00 & 0.00 & 0.00 & 0.00 \\
\hline Corn gluten meal & 2.30 & 4.60 & 6.90 & 9.30 \\
\hline Meat and bone meal & 1.41 & 2.82 & 4.23 & 5.65 \\
\hline Fish meal & 1.00 & 2.00 & 3.00 & 4.00 \\
\hline Palm kernel meal & 0.00 & 8.00 & 16.0 & 24.0 \\
\hline Soybean oil & 1.36 & 2.04 & 4.03 & 6.02 \\
\hline Dicalcium phosphate & 1.48 & 0.98 & 0.35 & 0.00 \\
\hline Limestone & 0.61 & 0.42 & 0.32 & 0.00 \\
\hline DL-methionine & 0.31 & 0.29 & 0.27 & 0.25 \\
\hline L-lysine $\mathrm{HCl}$ & 0.28 & 0.34 & 0.41 & 0.47 \\
\hline L-threonine & 0.09 & 0.10 & 0.12 & 0.13 \\
\hline Sodium chloride & 0.21 & 0.18 & 0.14 & 0.10 \\
\hline Sodium bicarbonate & 0.26 & 0.26 & 0.26 & 0.27 \\
\hline Trace mineral-vitamin premix ${ }^{1}$ & 0.23 & 0.23 & 0.23 & 0.23 \\
\hline Titanium dioxide & 0.30 & 0.30 & 0.30 & 0.30 \\
\hline \multicolumn{5}{|l|}{ Calculated analysis } \\
\hline Apparent metabolizable energy $(\mathrm{MJ} / \mathrm{kg})$ & 12.34 & 12.34 & 12.34 & 12.34 \\
\hline Apparent digestible protein & 18.80 & 18.80 & 18.80 & 18.80 \\
\hline Apparent digestible methionine & 0.62 & 0.62 & 0.63 & 0.63 \\
\hline Apparent digestible methionine + cysteine & 0.89 & 0.89 & 0.89 & 0.89 \\
\hline Apparent digestible lysine & 1.19 & 1.19 & 1.19 & 1.19 \\
\hline Apparent digestible threonine & 0.78 & 0.78 & 0.78 & 0.78 \\
\hline Apparent digestible arginine & 1.32 & 1.33 & 1.34 & 1.35 \\
\hline Apparent digestible valine & 0.91 & 0.93 & 0.95 & 0.97 \\
\hline Apparent digestible isoleucine & 0.80 & 0.80 & 0.80 & 0.80 \\
\hline Crude fat & 4.06 & 5.28 & 7.69 & 10.1 \\
\hline Crude fiber & 3.01 & 3.94 & 5.22 & 6.51 \\
\hline Calcium & 1.00 & 1.00 & 1.00 & 1.00 \\
\hline Available phosphorus & 0.50 & 0.50 & 0.50 & 0.50 \\
\hline$\beta$-mannan ${ }^{2}$ & 0.45 & 2.99 & 5.52 & 8.05 \\
\hline
\end{tabular}

${ }^{1}$ Supplied per kilogram of diet: vitamin A (vitamin A acetate), 12,000 IU; vitamin $\mathrm{D}_{3}$ (cholcalciferol), 4,000 IU; vitamin E (DL- $\alpha$-tocopherol), 80 IU; biotin, $0.25 \mathrm{mg}$; pantothenic acid (calcium-D-pantothenate), $15 \mathrm{mg}$; cyanocobalamin, $0.02 \mathrm{mg}$; folic acid, $3.0 \mathrm{mg}$; vitamin $\mathrm{K}_{3}$ (menadione nicotinamide bisulphite), $4.0 \mathrm{mg}$; niacin (nicotinic acid), $60 \mathrm{mg}$; pyridoxine (pyridoxine hydrochloride), $10 \mathrm{mg}$; riboflavin, $9.0 \mathrm{mg}$; thiamine (thiamine mononitrate), $3.0 \mathrm{mg}$; antioxidant (ethoxyquin), $100 \mathrm{mg}$; choline (choline chloride 60\%), $360 \mathrm{mg}$; Co (cobalt sulfate), $0.15 \mathrm{mg}$; Cu (copper sulfate), $6.0 \mathrm{mg}$; organic $\mathrm{Cu}$ (B-TRAXIM 2C G/Cu), $3.0 \mathrm{mg}$; Fe (iron sulfate), $36 \mathrm{mg}$; I (calcium iodate), $0.93 \mathrm{mg}$; Mn (manganese oxide), $60 \mathrm{mg}$; Mo (sodium molybdate), 0.15 $\mathrm{mg}$; Se (sodium selenite), $0.26 \mathrm{mg}$; organic Se (enriched yeast), $0.14 \mathrm{mg}$; Zn (zinc sulfate), $48 \mathrm{mg}$; organic Zn (B-TRAXIM 2C G/Zn), $24 \mathrm{mg}$.

${ }^{2} \beta$-mannan content of feed ingredients from Jackson (2010) was used for calculation.

New Zealand Code of Practice for the Care and Use of Animals for Scientific Purposes. One-d-old male broilers (Ross 308), obtained from a commercial hatchery, were individually weighed and allocated to 48 cages (eight birds per cage) in electrically heated battery brooders so that the average bird weight per cage was similar. Six cages were then randomly assigned to each of the eight dietary treatments. The birds were transferred to grower cages on $\mathrm{d}$ 12 and fed the same diets until d 21. The space allocation per bird in brooder and grower cages was 530 and $640 \mathrm{~cm}^{2}$, respectively. The battery brooders and grower cages were housed in an environmentally controlled room with $20 \mathrm{~h}$ of fluorescent illumination per day. The temperature was maintained at $31^{\circ} \mathrm{C}$ on $\mathrm{d} 1$, and was gradually reduced to $22^{\circ} \mathrm{C}$ by $21 \mathrm{~d}$ of age. Feed was offered ad libitum and water was freely available.

\section{Pellet durability}

Pellet durability was determined in a Holmen Pellet Tester (New Holmen NHP100 Portable Pellet Durability Tester, TekPro Ltd., Willow Park, North Walsham, Norfolk, UK) using the method described by Abdollahi et al. (2010). Clean pellet samples (100 g; four replicates per diet), with no fines, were rapidly circulated in an air stream around a 
perforated test chamber for $30 \mathrm{~s}$. Fines were removed continuously through the perforations during the test cycle. After the test cycle, the subject pellets were ejected and weighed manually. The pellet durability index (PDI) was calculated as the percentage of the pellets not passing through the perforations at the end of the test.

\section{Performance data}

Body weight and feed intake were recorded on a cage basis at weekly intervals. Mortality was recorded daily. Feed conversion ratio values were corrected for the body weight of any bird that died during the course of the experiment.

\section{Apparent metabolizable energy determination and excreta scoring}

Feed intake and total excreta output of each cage were quantitatively measured from d 18 to 21 post-hatch. Daily collections from each cage were pooled, mixed in a blender and sub-sampled. Sub-samples were lyophilized (Model 0610, Cuddon Engineering, Blenheim, New Zealand) ground to pass through a $0.5 \mathrm{~mm}$ sieve and stored in airtight plastic containers at $4^{\circ} \mathrm{C}$ pending analysis. The diets and excreta samples were analysed for dry matter (DM), gross energy (GE), nitrogen $(\mathrm{N})$, fat and NDF. On d 21, excreta were also scored for stickiness on a scale of 1 to 5 , with 1 representing normally formed excreta and 5 representing watery and very sticky excreta.

\section{Coefficient of ileal apparent digestibility determination}

On d 21, six birds per cage were euthanized by intravenous injection ( $1 \mathrm{~mL}$ per $2 \mathrm{~kg}$ live weight) of sodium pentobarbitone solution (Provet NZ Pty Ltd., Auckland, New Zealand) and ileal digesta were collected as described by Ravindran et al. (2005). The ileum was defined as that portion of the small intestine extending from the Meckel's diverticulum to a point $\sim 40 \mathrm{~mm}$ proximal to the ileo-caecal junction. The ileum was then divided into two halves and the digesta was collected from the lower half towards the ileo-caecal junction. Digesta from birds within a cage were pooled, lyophilized (Model 0610, Cuddon Engineering, Blenheim, New Zealand), ground to pass through a $0.5 \mathrm{~mm}$ sieve and stored at $4^{\circ} \mathrm{C}$ until laboratory analysis. The diets and digesta samples were analysed for GE, titanium dioxide (Ti), N, starch, fat, and NDF.

\section{Chemical analysis}

Dry matter was determined using standard procedures (method 930.15; AOAC, 2005). Gross energy was determined by adiabatic bomb calorimetry (Gallenkamp Autobomb, London, UK) standardized with benzoic acid. Samples were assayed for $\mathrm{Ti}$ on a UV spectrophotometer following the method of Short et al. (1996). The NDF was determined using standard procedures (AOAC, 2005).

Nitrogen was determined by combustion (method 968.06; AOAC, 2005) using a CNS-200 carbon, $\mathrm{N}$ and sulphur auto analyser (LECO Corporation, St. Joseph, MI, USA). Starch was determined using the Megazyme Total Starch Assay kit (Megazyme International Ireland Ltd., Wicklow, Ireland) based on thermostable $\alpha$-amylase and amyloglucosidase. Fat was determined using Soxhlet extraction procedure (method 991.36; AOAC, 2005).

\section{Calculations}

All data were expressed on a DM basis, and the AME was calculated using the following formula:

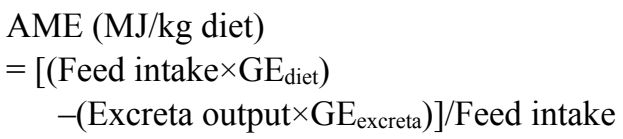

Nitrogen-corrected AME (AMEn) was determined by correction for zero $\mathrm{N}$ retention by simple multiplication with $36.54 \mathrm{~kJ}$ per gram $\mathrm{N}$ retained in the body as described by Hill and Anderson (1958).

Coefficient of apparent ileal digestibility (CAID) of nutrients was calculated using the following formula:

CAID of diet component

$=\left[(\text { Diet component } / \mathrm{Ti})_{\operatorname{diet}}\right.$

$$
\text { -(Diet component/Ti } \left.)_{\text {ileal }}\right] /(\text { Diet component/Ti })_{\text {diet }}
$$

Where (Diet component/Ti $)_{\text {diet }}=$ ratio of diet component to $\mathrm{Ti}$ in the diet, and

(Diet component/Ti) $)_{\text {ileal }}$

$=$ ratio of diet component to $\mathrm{Ti}$ in the ileal digesta

Total tract retention (TTR) of nutrients, as a percentage of intake, was determined as follows:

$$
\begin{aligned}
& \operatorname{TTR}(\%)=100 \times\left\{\left[\left(\text { Feed intake } \times \text { Nutrient }_{\text {diet }}\right)\right.\right. \\
& \text {-(Excreta output } \times \text { Nutrient } \text { excreta })] \\
& \left./\left(\text { Feed intake } \times \text { Nutrient }_{\text {diet }}\right)\right\}
\end{aligned}
$$

\section{Statistical analysis}

The data were analysed by two-way analysis of variance to determine the main effects (PKM inclusion and enzyme addition) and their interaction using the General Linear Models procedure of SAS (2004). Cage means served as the experimental unit for all data. Differences were considered to be significant at $\mathrm{p}<0.05$ and significant differences between means were separated by the Least Significant Difference test. 


\section{RESULTS}

\section{Pellet durability index}

Increasing the dietary PKM inclusion resulted in lower PDI compared to the diet with no PKM. The PDI values of 85.3, 56.2, 34.4 and 15.4, respectively, were obtained with PKM inclusion of $0 \%, 8 \%, 16 \%$, and $24 \%$.

\section{Performance and, excreta score and dry matter}

Mortality during the performance experiment was negligible. Only six out of the 384 birds died and the deaths were not related to any specific treatment.

The performance data of broiler starters from $d 1$ to 21 post-hatch is shown in Table 2. Weight gain of the birds was significantly $(p<0.001)$ influenced by PKM inclusion and enzyme addition. Inclusion of $8.0 \%$ and $16 \%$ PKM increased $(p<0.05)$ the weight gain compared to the PKM0 diet. Weight gain was severely reduced by feeding the PKM24 diets. Enzyme supplementation increased weight gain $(p<0.05)$, irrespective of PKM inclusion level.

There was a significant $(\mathrm{p}<0.001)$ effect of PKM inclusion on feed intake with birds fed the PKM8 diets had the highest feed intake $(p<0.05)$. Birds fed the PKM0 and PKM16 diets showed similar feed intake. Similar to weight gain, inclusion of $24 \%$ PKM resulted in the lowest $(\mathrm{p}<0.05)$ feed intake. Neither the main effect of enzyme addition nor the PKM inclusion $\times$ enzyme addition interaction was significant for feed intake.

A significant $(p<0.01)$ interaction between PKM inclusion and enzyme addition was detected for FCR of birds. In PKM0 and PKM8 diets, enzyme addition significantly $(\mathrm{p}<0.05)$ improved feed efficiency; whereas, enzyme addition had no effect on feed per gain of birds fed the diets with PKM inclusion above $8.0 \%$.

There was a significant $(\mathrm{p}<0.001)$ effect of PKM inclusion on excreta score and excreta DM (Table 2). As the PKM level was increased, the excreta DM increased and excreta score decreased. Neither the main effect of enzyme addition nor the interaction between PKM inclusion and enzyme addition was significant for excreta score and DM.

\section{Nutrient digestibility}

A significant $(\mathrm{p}<0.05)$ PKM inclusion $\times$ enzyme addition interaction was observed for the CAID of $\mathrm{N}$ and GE (Table 3). In PKM0 and PKM16 diets, enzyme addition significantly $(\mathrm{p}<0.05)$ increased $\mathrm{N}$ and GE digestibility but had no effect in the PKM8 and PKM24 diets.

The main effect of PKM inclusion was significant

Table 2. Influence of inclusion level of palm kernel meal (PKM) and enzyme addition on the weight gain (g/bird), feed intake (g/bird), feed conversion ratio (FCR; g feed/g gain), excreta score and excreta dry matter (DM; \%) of broiler starters ${ }^{1}$ (d 1 to 21 post-hatch)

\begin{tabular}{|c|c|c|c|c|c|c|}
\hline PKM inclusion & Enzyme addition & Weight gain & Feed intake & FCR & Excreta score $^{2}$ & Excreta $\mathrm{DM}^{2}$ \\
\hline \multirow[t]{2}{*}{ PKM0 } & - & 965 & 1,138 & $1.197^{\mathrm{a}}$ & 4.00 & 24.4 \\
\hline & + & 978 & 1,122 & $1.146^{\mathrm{b}}$ & 4.00 & 25.0 \\
\hline \multirow[t]{2}{*}{ PKM8 } & - & 988 & 1,178 & $1.189^{\mathrm{a}}$ & 2.75 & 29.2 \\
\hline & + & 1,003 & 1,164 & $1.160^{\mathrm{b}}$ & 2.58 & 29.2 \\
\hline \multirow[t]{2}{*}{ PKM16 } & - & 973 & 1,110 & $1.141^{\mathrm{b}}$ & 2.00 & 34.6 \\
\hline & + & 1,003 & 1,134 & $1.139^{\mathrm{b}}$ & 2.00 & 34.0 \\
\hline \multirow[t]{2}{*}{ PKM24 } & - & 914 & 1,041 & $1.144^{\mathrm{b}}$ & 1.25 & 36.4 \\
\hline & + & 936 & 1,067 & $1.145^{\mathrm{b}}$ & 1.25 & 37.0 \\
\hline $\mathrm{SEM}^{3}$ & & 7.7 & 11.8 & 0.0077 & 0.087 & 0.71 \\
\hline \multicolumn{7}{|l|}{ Main effects } \\
\hline \multicolumn{7}{|l|}{ PKM inclusion } \\
\hline PKM0 & & $972^{\mathrm{b}}$ & $1,130^{\mathrm{b}}$ & 1.171 & $4.00^{\mathrm{a}}$ & $24.7^{\mathrm{d}}$ \\
\hline PKM8 & & $996^{\mathrm{a}}$ & $1,171^{\mathrm{a}}$ & 1.174 & $2.67^{\mathrm{b}}$ & $29.2^{\mathrm{c}}$ \\
\hline PKM16 & & $988^{\mathrm{a}}$ & $1,122^{\mathrm{b}}$ & 1.140 & $2.00^{\mathrm{c}}$ & $34.3^{\mathrm{b}}$ \\
\hline PKM24 & & $925^{\mathrm{c}}$ & $1,054^{\mathrm{c}}$ & 1.145 & $1.25^{\mathrm{d}}$ & $36.7^{\mathrm{a}}$ \\
\hline \multicolumn{7}{|l|}{ Enzyme addition } \\
\hline- & & $960^{\mathrm{b}}$ & 1,117 & 1.168 & 2.50 & 31.2 \\
\hline+ & & $980^{\mathrm{a}}$ & 1,122 & 1.147 & 2.46 & 31.3 \\
\hline \multicolumn{7}{|l|}{ Probabilities, $\mathrm{p} \leq$} \\
\hline PKM inclusion & & 0.001 & 0.001 & 0.001 & 0.001 & 0.001 \\
\hline Enzyme addition & & 0.001 & 0.557 & 0.001 & 0.504 & 0.768 \\
\hline PKM inclusion $\times$ enzyme additi & ion & 0.692 & 0.137 & 0.004 & 0.716 & 0.806 \\
\hline
\end{tabular}


Table 3. Influence of inclusion level of palm kernel meal (PKM) and enzyme addition on coefficient of apparent ileal digestibility of nitrogen $(\mathrm{N})$, starch, fat, gross energy (GE), and neutral detergent fiber (NDF) in broiler starters ${ }^{1}$

\begin{tabular}{|c|c|c|c|c|c|c|}
\hline PKM inclusion & Enzyme addition & $\mathrm{N}$ & Starch & Fat & GE & $\mathrm{NDF}$ \\
\hline \multirow[t]{2}{*}{ PKM0 } & - & $0.745^{\mathrm{c}}$ & 0.944 & 0.886 & $0.693^{b}$ & 0.108 \\
\hline & + & $0.784^{\mathrm{ab}}$ & 0.949 & 0.905 & $0.718^{\mathrm{a}}$ & 0.158 \\
\hline \multirow[t]{2}{*}{ PKM8 } & - & $0.787^{\mathrm{ab}}$ & 0.990 & 0.921 & $0.727^{\mathrm{a}}$ & 0.164 \\
\hline & + & $0.779^{\mathrm{ab}}$ & 0.989 & 0.917 & $0.721^{\mathrm{a}}$ & 0.172 \\
\hline \multirow[t]{2}{*}{ PKM16 } & - & $0.765^{b c}$ & 0.986 & 0.919 & $0.688^{b c}$ & 0.203 \\
\hline & + & $0.795^{\mathrm{a}}$ & 0.984 & 0.938 & $0.722^{\mathrm{a}}$ & 0.292 \\
\hline \multirow[t]{2}{*}{ PKM24 } & - & $0.752^{\mathrm{c}}$ & 0.990 & 0.949 & $0.675^{b c}$ & 0.236 \\
\hline & + & $0.746^{\mathrm{c}}$ & 0.984 & 0.938 & $0.669^{\mathrm{c}}$ & 0.259 \\
\hline SEM $^{2}$ & & 0.0087 & 0.0025 & 0.0100 & 0.0078 & 0.0184 \\
\hline \multicolumn{7}{|l|}{ Main effects } \\
\hline \multicolumn{7}{|l|}{ PKM inclusion } \\
\hline PKM0 & & 0.765 & $0.947^{b}$ & $0.896^{\mathrm{c}}$ & 0.706 & $0.133^{\mathrm{b}}$ \\
\hline PKM8 & & 0.783 & $0.989^{\mathrm{a}}$ & $0.919^{b}$ & 0.724 & $0.168^{\mathrm{b}}$ \\
\hline PKM16 & & 0.780 & $0.985^{\mathrm{a}}$ & $0.928^{\mathrm{ab}}$ & 0.705 & $0.248^{\mathrm{a}}$ \\
\hline PKM24 & & 0.749 & $0.987^{\mathrm{a}}$ & $0.943^{\mathrm{a}}$ & 0.672 & $0.248^{\mathrm{a}}$ \\
\hline \multicolumn{7}{|l|}{ Enzyme addition } \\
\hline- & & 0.762 & 0.977 & 0.919 & 0.696 & $0.178^{b}$ \\
\hline+ & & 0.776 & 0.977 & 0.925 & 0.707 & $0.220^{\mathrm{a}}$ \\
\hline \multicolumn{7}{|l|}{ Probabilities, $\mathrm{p} \leq$} \\
\hline PKM inclusion & & 0.001 & 0.001 & 0.001 & 0.001 & 0.001 \\
\hline Enzyme additi & & 0.032 & 0.678 & 0.440 & 0.045 & 0.002 \\
\hline PKM inclusion & ddition & 0.016 & 0.170 & 0.316 & 0.022 & 0.152 \\
\hline
\end{tabular}

${ }^{1}$ Each value represents the mean of six replicates (six birds per replicate) measured on d 21 post-hatch.

${ }^{2}$ Pooled standard error of mean.

Means in a column not sharing a common letter $\left({ }^{a, b, c}\right)$ are significantly different $(\mathrm{p}<0.05)$.

$(\mathrm{p}<0.001)$ for the CAID of starch and fat. Inclusion of PKM into the basal diet, irrespective of inclusion level, enhanced $(\mathrm{p}<0.05)$ starch and fat digestibility. Whereas the PKMcontaining diets resulted in similar starch digestibility, the PKM24 diet had the highest CAID of fat. Neither the main effect of enzyme addition nor the interaction between PKM inclusion and enzyme addition was significant for the CAID of starch and fat.

Inclusion of PKM at $16 \%$ and $24 \%$ resulted in similar CAID of NDF but higher $(\mathrm{p}<0.05)$ than the PKM0 and PKM8 diets. Enzyme addition, regardless of level of PKM inclusion, significantly $(p<0.05)$ increased CAID of NDF.

\section{Nutrient retention and energy utilization}

Significant PKM inclusion $\times$ enzyme addition interaction was observed for TTR of DM $(p<0.05)$ and NDF $(p<0.001$; Table 4). Enzyme inclusion had no effect on TTR of DM and NDF in the PKM8 and PKM24 diets, but improved DM and NDF retention in the PKM0 and PKM16 diets.

The main effect of PKM inclusion was significant for the TTR of $\mathrm{N}(\mathrm{p}<0.001)$ and fat $(\mathrm{p}<0.01)$. Diets with no PKM and $8.0 \%$ PKM resulted in higher $\mathrm{N}$ retention compared to those with $16 \%$ and $24 \%$ PKM. Inclusion of $24 \%$ PKM resulted in the lowest $\mathrm{N}$ retention. Birds fed the
PKM8 diets had higher $(\mathrm{p}<0.05)$ fat retention compared to other PKM inclusion levels.

Increasing the inclusion level of PKM significantly $(p<0.001)$ decreased the TTR of GE. Enzyme addition enhanced $(\mathrm{p}<0.05)$ GE retention.

Pam kernel meal inclusion influenced AMEn $(p<0.05)$. There was a significant decrease in AMEn with PKM inclusion of $24 \%$. There was no effect of enzyme addition on energy utilization.

\section{DISCUSSION}

Unexpectedly, feeding the PKM8 and PKM16 diets increased weight gain of broilers. Ezieshi and Olomu (2008) reported impaired body weight and feed efficiency in a broiler study with $30 \%$ and $32.5 \%$ PKM inclusion in starter and finisher diets, respectively. Mardhati et al. (2011) also reported that weight gain and feed efficiency of broilers were poorer in diet with $20 \%$ PKM compared to a cornbased control diet. Reduced body weight and feed efficiency have also been reported with PKM inclusion levels above $10 \%$ (Soltan, 2009). In most of the studies investigating the effect of PKM inclusion in broiler diets, PKM has been included into a control diet either at the 
Table 4. Influence of inclusion level of palm kernel meal (PKM) and enzyme addition on total tract retention of dry matter (DM), nitrogen $(\mathrm{N})$, fat, neutral detergent fiber (NDF), gross energy (GE), and nitrogen-corrected apparent metabolizable energy (AMEn) in broiler starters ${ }^{1}$

\begin{tabular}{|c|c|c|c|c|c|c|c|}
\hline PKM inclusion & Enzyme addition & $\mathrm{DM}$ & $\mathrm{N}$ & Fat & NDF & GE & AMEn \\
\hline \multirow[t]{2}{*}{ PKM0 } & - & $72.2^{b}$ & 67.6 & 90.0 & $22.4^{\mathrm{d}}$ & 76.2 & 13.35 \\
\hline & + & $73.5^{\mathrm{a}}$ & 69.2 & 90.7 & $27.4^{\mathrm{b}}$ & 77.1 & 13.52 \\
\hline \multirow[t]{2}{*}{ PKM8 } & - & $71.4^{\mathrm{c}}$ & 68.4 & 91.6 & $23.2^{\mathrm{cd}}$ & 75.3 & 13.45 \\
\hline & + & $71.5^{\mathrm{bc}}$ & 68.0 & 92.1 & $24.4^{\mathrm{c}}$ & 75.6 & 13.50 \\
\hline \multirow[t]{2}{*}{ PKM16 } & - & $67.0^{\mathrm{e}}$ & 64.7 & 90.8 & $23.7^{\mathrm{cd}}$ & 71.6 & 13.33 \\
\hline & + & $67.7^{\mathrm{d}}$ & 65.1 & 90.6 & $28.7^{\mathrm{b}}$ & 72.3 & 13.45 \\
\hline \multirow[t]{2}{*}{ PKM24 } & - & $63.1^{\mathrm{f}}$ & 60.3 & 91.0 & $30.7^{\mathrm{a}}$ & 68.7 & 13.36 \\
\hline & + & $62.8^{f}$ & 59.7 & 90.0 & $31.2^{\mathrm{a}}$ & 68.5 & 13.27 \\
\hline SEM $^{2}$ & & 0.26 & 0.49 & 0.43 & 0.66 & 0.25 & 0.055 \\
\hline \multicolumn{8}{|l|}{ Main effects } \\
\hline \multicolumn{8}{|l|}{ PKM inclusion } \\
\hline PKM0 & & 72.9 & $68.4^{\mathrm{a}}$ & $90.4^{\mathrm{b}}$ & 24.9 & $76.7^{\mathrm{a}}$ & $13.43^{\mathrm{a}}$ \\
\hline PKM8 & & 71.4 & $68.2^{\mathrm{a}}$ & $91.9^{\mathrm{a}}$ & 23.8 & $75.4^{\mathrm{b}}$ & $13.47^{\mathrm{a}}$ \\
\hline PKM16 & & 67.3 & $64.9^{\mathrm{b}}$ & $90.7^{\mathrm{b}}$ & 26.2 & $71.9^{\mathrm{c}}$ & $13.39^{\mathrm{ab}}$ \\
\hline PKM24 & & 63.0 & $60.0^{c}$ & $90.5^{\mathrm{b}}$ & 30.9 & $68.6^{\mathrm{d}}$ & $13.31^{\mathrm{b}}$ \\
\hline \multicolumn{8}{|l|}{ Enzyme addition } \\
\hline- & & 68.4 & 65.2 & 90.9 & 25.0 & $72.9^{b}$ & 13.37 \\
\hline+ & & 68.9 & 65.5 & 90.8 & 27.9 & $73.4^{\mathrm{a}}$ & 13.43 \\
\hline \multicolumn{8}{|l|}{ Probabilities, $\mathrm{p} \leq$} \\
\hline PKM inclusion & & 0.001 & 0.001 & 0.005 & 0.001 & 0.001 & 0.036 \\
\hline Enzyme addition & & 0.013 & 0.439 & 0.849 & 0.001 & 0.022 & 0.112 \\
\hline PKM inclusion $\times$ en & e addition & 0.016 & 0.098 & 0.203 & 0.001 & 0.137 & 0.105 \\
\hline
\end{tabular}

Means in a column not sharing a common letter $(\mathrm{a}, \mathrm{b}, \mathrm{c}, \mathrm{d}, \mathrm{e}, \mathrm{f})$ are significantly different $(\mathrm{p}<0.05)$.

${ }^{1}$ Each value represents the mean of six replicates (eight birds per replicate) measured from d 18 to 21 post-hatch.

${ }^{2}$ Pooled standard error of mean.

expense of an ingredient (usually the major cereal) in the diet with the consequence of decreased nutrient density or without considering the AA digestibility of PKM. In all the above-mentioned studies, the digestibility of the protein and $\mathrm{AA}$ in PKM was not considered and the diets were formulated based on the total protein and AA contents and not the digestible contents. Palm kernel meal has been reported to have a poor protein digestibility (Bryden et al., 2009, CAID of 0.54; Abdollahi et al., 2015, standardized ileal digestibility coefficient of 0.42 to 0.46 ); which implies that formulating PKM-containing diets based on total crude protein content will fail to meet the birds' requirement for a balanced diet and impair the growth performance of broilers. Use of digestible AA contents of PKM when formulating broiler diets will eliminate this error and hold a promise to increase the inclusion levels of PKM in practical poultry diets. The PKM sample used in the current study had been previously assessed for the AME and digestible AA contents (Abdollahi et al., 2015), and the data was used to formulate the experimental diets based on apparent digestible AA content. It must be noted that both digestible AA systems, apparent or standardized, are superior to the total AA system. The choice of the appropriate system of digestible AA depends on the method of formulating diets, with CAID being suggested as the most appropriate system to use when the diets are formulated to least-cost (Bryden et al., 2009).

Birds fed the PKM8 diets consumed more feed than other dietary treatments. In agreement to the current study, Adrizal et al. (2011) reported an increased feed intake with increasing PKM level from $0 \%$ to $15 \%$ and $30 \%$ in laying hens. The higher feed intake in birds fed PKM-containing diets has also been reported by other researchers (Onifade and Babatunde, 1998; Sundu et al., 2005; Ezieshi and Olomu, 2008). This observation was attributed to its faster passage rate in the digestive tract (Onifade and Babatunde, 1998), high bulk density and low water holding capacity (Sundu et al., 2006). Onifade and Babatunde (1998) speculated that the higher feed intake in birds fed high levels of PKM in diets was an attempt by the bird to compensate the dilution of the diets and to consume enough nutrients to achieve comparable growth.

Inclusion of $24 \%$ PKM in the current study, however, was associated with a marked depression in weight gain, a finding which does not support the implication from several researchers (Panigrahi and Powell, 1991; Perez et al., 2000; Sundu et al., 2006; Adrizal et al., 2011) reporting that PKM can be included in poultry diets up to $40 \%$ without 
impairing performance parameters. Weight gain deterioration of birds fed PKM24 diets although corresponded with the lowest TTR of DM, N and GE, and AMEn, might be explained largely by the feed intake depression at this PKM level. Pellet durability was found to deteriorate with increasing dietary PKM inclusions. This is mostly evidenced by the lowest PDI value determined in the PKM24 diet. Deteriorated pellet quality is also likely to be responsible, in part, for the lowest feed intake and weight gain observed with feeding PKM24 diets.

The present data demonstrated a weight gain response to dietary enzyme addition, even in the PKM0 diet. Enzyme supplementation improved feed efficiency at inclusion levels of $0 \%$ and $8 \%$ PKM. Although viscosity is not a major nutritional obstacle in corn-based diets, the advantages of exogenous NSP-degrading enzymes on nutrient and energy utilization and broiler performance in corn-based diets have been previously reported (Zanella et al., 1999; Kiarie et al., 2014). In a recent study, Kiarie et al. (2014) reported that xylanase supplementation improved growth performance, nutrient and energy utilization in both wheat- and corn-based diets. The release of previously entrapped nutrients, and not the viscosity reduction, due to hydrolysis of structural arabinoxylans accounted for the positive response to xylanase addition in corn-based diets. These researchers suggested that young birds are sensitive to both soluble and insoluble NSP and could benefit from NSP-degrading enzymes independent of the source of cereal in the diets. In agreement with the current study, Williams et al. (2014) found that supplementation of a cornsoy diet with $\beta$-mannanase and a carbohydrase cocktail, separately and intermittently, improved body weight and feed efficiency in broilers. These researchers speculated that the application of a cocktail carbohydrase in corn-soy diets might be the most effective strategy to eliminate the negative effects of various NSP components and to improve the nutrient availability in these conventional feedstuffs.

The beneficial effects of supplementing the poultry diets with $\beta$-mannanase have been shown in several studies (Lee et al., 2003; Daskiran et al., 2004; Jackson et al., 2004; Zou et al., 2006; Williams et al., 2014). Lee et al. (2003) reported that supplementation of $\beta$-mannanase to cornbased broilers diets containing guar meal reduced intestinal viscosity and enhanced body weight and feed efficiency. Improved feed efficiency as a result of degrading $\beta$ mannans through $\beta$-mannanase supplementation in a cornsoy-based broiler diet has also been reported by Daskiran et al. (2004). Jackson et al. (2004) reported an improved weight gain and feed efficiency in broilers fed corn-soybean meal based diets supplemented with $\beta$-mannanase. The positive growth responses might be, partly, explained by a reduction in energy-draining immune stimulation associated with a decrease in the concentration of $\beta$-mannan in the digestive tract of bird. In the current study, calculated $\beta$ mannan contents of the PKM0, PKM8, PKM16, and PKM24 diets were 4.50, 29.9, 55.2, and $80.5 \mathrm{~g} / \mathrm{kg}$, respectively. It has been shown that $\beta$-mannans are components of the surface of many pathogens and perceived by animals as a pathogen-associated antigens stimulating the innate immune system of animals (Jackson et al., 2004; Hsiao et al., 2006; Williams et al., 2014). This immune response, termed as feed-induced immune response, deteriorates animal performance by diverting the energy from growth toward an energy-consuming immune response (Hsiao et al., 2006; Williams et al., 2014). It has been suggested that the inclusion of exogenous $\beta$ mannanase hydrolyses the high molecular weight $\beta$ mannans into mannose-oligosaccharides which are not recognisable by immune systems. By reducing the immune responses induced by feed, $\beta$-mannanase has been shown to spare the energy for production (Williams et al., 2014).

The fact that enzyme supplementation had no effect on the FCR of birds fed PKM16 and PKM24 diets is probably due, in large part, to the fact that the inclusion of PKM at these levels significantly improved feed efficiency compared to the PKM0 and PKM8 diets with no enzyme supplementation. Moreover, there is possibility that $\beta$ mannanase inclusion in diets with PKM levels above $8 \%$ was not sufficient to hydrolyse $\beta$-1,4-glucosidic linkages in $\beta$-mannan and to generate performance responses. Daskiran et al. (2004), in a broiler study with diets varying in $\beta$ mannan contents, found that diets with higher $\beta$-mannan content require higher levels of endo- $\beta$-D-mannanase supplementation. These researchers suggested that when ingredients high in $\beta$-mannan, such as PKM, copra meal or guar gum, are included in broiler diets, both the dietary enzyme and $\beta$-mannan levels should be monitored.

Enzyme supplementation increased the CAID of NDF and TTR of GE. Surprisingly, enzyme addition enhanced CAID of N and GE, and TTR of DM and NDF only in PKM0 and PKM16 diets and not in PKM8 and PKM24; a finding which is not readily explainable. Degradation of NSP by the enzyme cocktail, containing $\beta$-mannanase, xylanase, amylase, protease, cellulase and glucanase, might partially explain the positive effect of enzyme addition on nutrient utilization. Corn and soybean meal, though the most common feedstuffs in poultry diets, contain considerable amount of NSP. While corn contains a negligible amount of soluble NSP, it has been reported to have a concentration of insoluble NSP of $80 \mathrm{~g} / \mathrm{kg}$ which consists mainly of arabinoxylans and $\beta$-glucans (Choct, 2006). Ravindran et al. (2014) reported average insoluble and soluble NSP contents of 171 and $16 \mathrm{~g} / \mathrm{kg}$, respectively, in soybean meal. A typical corn-soy diet has been reported to contain $123 \mathrm{~g} \mathrm{NSP} / \mathrm{kg}$, with 111 and $12 \mathrm{~g} / \mathrm{kg}$ of the NSP being in the form of insoluble and soluble NSP, respectively 
(Abdollahi et al., 2010). Palm kernel meal sample used in the current study contained 686 and $610 \mathrm{~g} / \mathrm{kg}$ of NDF and total NSP, respectively (Abdollahi et al., 2015). Saenphoom et al. $(2011 ; 2013)$ reported that pre-treating palm kernel expeller with exogenous enzyme reduced hemicellulose and cellulose contents by $26 \%$ and $33 \%$, respectively. Olaniyi (2014) reported significant reductions in fiber content of PKM as a result of hydrolysing PKM with $\beta$-mannanase at $30^{\circ} \mathrm{C}$ for $60 \mathrm{~h}$. It is also possible that NSP-degrading enzymes by releasing the $\beta$-mannans encapsulated in intact cell walls, which can be then depolymerised by $\beta$ mannanase, might synergize with $\beta$-mannanase as shown by Williams et al. (2014). Aya et al. (2013), using a combination of enzymes containing $\beta$-mannanase, $\alpha$ galactosidase, xylanase, cellulase and glucanase activity, reported higher nutrient (including fiber) retention in enzyme-supplemented diets independent of PKM inclusion level $(10 \%, 20 \%, 30 \%$, and $40 \%)$; an improvement which contributed to the higher weight gain and feed efficiency.

\section{CONCLUSIONS}

The present data are suggestive of the potential for PKM to be included in broiler diets. If PKM is to be used in broiler diets, formulating diets based on digestible AA contents and enzyme supplementation are strategies to support optimum growth performance of broilers. When PKM-containing diets are balanced on a digestible AA basis, PKM can be included in broiler diets up to $16 \%$ with no deleterious effects on growth performance. Further studies are warranted to elucidate the effects of higher $\beta$-mannanase activity, individually or in combination, with NSPdegrading enzymes in broiler diets containing PKM.

\section{CONFLICT OF INTEREST}

We certify that there is no conflict of interest with any financial organization regarding the material discussed in the manuscript.

\section{ACKNOWLEDGMENTS}

We would like to gratefully acknowledge the financial support of the AsiaPac (Dongguan) Biotechnology Co. Ltd. (Guangdong, China) under project APD13001 "Use of $\beta$ mannanase in enzyme complexes to enhance the utilization of PKM in poultry diets".

\section{REFERENCES}

Abdollahi, M. R., B. Hosking, and V. Ravindran. 2015. Nutrient analysis, metabolizable energy and ileal amino acid digestibility of palm kernel meal for broilers. Anim. Feed Sci. Technol. 206:119-125.
Abdollahi, M. R., V. Ravindran, T. J. Wester, G. Ravindran, and D. V. Thomas. 2010. Influence of conditioning temperature on performance, apparent metabolisable energy, ileal digestibility of starch and nitrogen and the quality of pellets, in broiler starters fed maize- and sorghum-based diets. Anim. Feed Sci. Technol. 162:106-115.

Adrizal, A., Y. Yusrizal, S. Fakhri, W. Haris, E. Ali, and C. R. Angel. 2011. Feeding native laying hens diets containing palm kernel meal with or without enzyme supplementations: 1. Feed conversion ratio and egg production. J. Appl. Poult. Res. 20:40-49.

Almaguer, B. L., R. C. Sulabo, Y. Liu, and H. H. Stein. 2014. Standardized total tract digestibility of phosphorus in copra meal, palm kernel expellers, palm kernel meal, and soybean meal fed to growing pigs. J. Anim. Sci. 92:2473-2480.

AOAC. 2005. Official Methods of Analysis. 18th edn. Association of Official Analytical Chemists, Gaithersburg, MD, USA.

Aya, V. E., B. A. Ayanwale, A. T. Ijaiya, and A. Aremu. 2013. Performance and nutrient digestibility in broiler chicks as influenced by multi enzyme addition to starter diets containing palm kernel meal. Biotechnol. Anim. Husb. 29:93-104.

Bryden, W. L., X. Li, G. Ravindran, L. I. Hew, and V. Ravindran. 2009. Ileal digestible amino acid values in feedstuffs for poultry. RIRDC Publication No 09/071. Rural Industries Research and Development Corporation, Canberra, Australia.

Choct, M. 2006. Enzymes for the feed industry: Past, present and future. World's Poult. Sci. J. 62:5-16.

Daskiran, M., R. G. Teeter, D. Fodge, and H. Y. Hsiao. 2004. An evaluation of endo- $\beta$-D-mannanase (Hemicell) effects on broiler performance and energy use in diets varying in $\beta$ mannan content. Poult. Sci. 83:662-668.

Daud, M. J. and M. C. Jarvis. 1992. Mannan of oil palm kernel. Phytochemistry 31:463-464.

Dusterhoft, E. M., A. G. J. Voragen, and F. M. Engles. 1991. Nonstarch polysaccharides from sunflower (Helianthus annuus) meal and palm kernel (Elaeis guineensis) meal- preparation of cell wall material and extraction of polysaccharide fractions. J. Sci. Food Agric. 55:411-422.

Ezieshi, E. V. and J. M. Olomu. 2008. Nutritional evaluation of palm kernel meal types: 2. Effects on live performance and nutrient retention in broiler chicken diets. Afr. J. Biotechnol. 7:1171-1175

Hill, F. W. and D. L. Anderson. 1958. Comparison of metabolizable energy and productive energy determinations with growing chicks. J. Nutr. 64:587-603.

Hsiao, H. Y., D. M. Anderson, and N. M. Dale. 2006. Levels of $\beta$ mannan in soybean meal. Poult. Sci. 85:1430-1432.

Jackson, M. E. 2010. Mannanase, alpha-galactosidase and pectinase. In: Enzymes in Farm Animal Nutrition, 2nd Ed. (Eds. M. R. Bedford and G. G. Partridge). CABI, Wallingford, Oxfordshire, UK. pp. 54-84.

Jackson, M. E., K. Geronian, A. Knox, J. McNab, and E. McCartney. 2004. A dose-response study with the feed enzyme $\beta$-mannanase in broilers provided with corn-soybean meal based diets in the absence of antibiotic growth promoters. Poult. Sci. 83:1992-1996.

Kiarie, E., L. F. Romero, and V. Ravindran. 2014. Growth performance, nutrient utilization, and digesta characteristics in broiler chickens fed corn or wheat diets without or with 
supplemental xylanase. Poult. Sci. 93:1186-1196.

Knudsen, K. E. B. 1997. Carbohydrate and lignin contents of plant materials used in animal feeding. Anim. Feed Sci. Technol. 67:319-338.

Lee, J. T., C. A. Bailey, and A. L. Cartwright. 2003. $\beta$-mannanase ameliorates viscosity-associated depression of growth in broiler chickens fed guar germ and hull fractions. Poult. Sci. 82:1925-1931.

Mardhati, M., H. K. Wong, and S. Noraini. 2011. Growth performance and carcass quality of broilers fed with palm kernel meal-based rations. J. Trop. Agric. Food Sci. 39:157166.

Olaniyi, O. O. 2014. Effect of beta-mannanse treatment on nutritive quality of palm kernel meal. Afr. J. Microbiol. Res. 8:2405-2410.

Onifade, A. A. and G. M. Babatunde. 1998. Comparison of the utilization of palm kernel meal, brewers' dried grains and corn offal by broiler chicks. Br. Poult. Sci. 39:245-250.

Panigrahi, S. and C. J. Powell. 1991. Effects of high rates of inclusion of palm kernel meal in broiler chick diets. Anim. Feed Sci. Technol. 34:37-47.

Perez, J. F., A. G. Gernat, and J. G. Murillo. 2000. The effect of different levels of palm kernel meal in layer diets. Poult. Sci. 79:77-79.

Ravindran, V., L. I. Hew, G. Ravindran, and W. L. Bryden. 2005. Apparent ileal digestibility of amino acids in feed ingredients for broiler chickens. Anim. Sci. 81:85-97.

Ravindran, V., M. R. Abdollahi, and S. M. Bootwalla. 2014. Nutrient analysis, metabolizable energy, and digestible amino acids of soybean meals of different origins for broilers. Poult. Sci. 93:2567-2577.

Ross, 2007. Ross 308 Broiler: Nutrition Specification, June 2007. Ross Breeders Limited, Newbridge, Midlothian, Scotland, UK.

Saenphoom, P., J. B. Liang, Y. W. Ho, T. C. Loh, and M. Rosfarizan. 2013. Effects of enzyme treated palm kernel expeller on metabolizable energy, growth performance, villus height and digesta viscosity in broiler chickens. Asian Australas. J. Anim. Sci. 26:537-544.
Saenphoom, P., J. B. Liang, Y. W. Ho, T. C. Loh, and M. Rosfarizan. 2011. Effect of enzyme treatment on chemical composition and production of reducing sugars in palm (Elaeis guineenis) kernel expeller. Afr. J. Biotechnol. 10:15372-15377.

SAS Institute Inc. 2004. SAS/STAT User's Guide. Version 9.1.2. SAS Institute Inc., Cary, NC, USA.

Shakila, S., P. Sudhakara Reddy, P. V. V. S. Reddy, J. V. Ramana, and A. Ravi. 2012. Effect of palm kernel meal on the performance of broilers. Tamilnadu J. Vet. Anim. Sci. 8:227234

Short, F. J., P. Gorton, J. Wiseman, and K. N. Boorman. 1996. Determination of titanium dioxide added as an inert marker in chicken digestibility studies. Anim. Feed Sci. Technol. 59:215221

Soltan, M. A. 2009. Growth performance, immune response and carcass traits of broiler chicks fed on graded levels of palm kernel cake without or with enzyme supplementation. Livest. Res. Rural Dev. 21, Article \#37.

Sundu, B., A. Kumar, and J. Dingle. 2006. Palm kernel meal in broiler diets: effect on chicken performance and health. World's Poult. Sci. J. 62:316-325.

Sundu, B., A. Kumar, and J. Dingle. 2005. Response of birds fed increasing levels of palm kernel meal supplemented with enzymes. Proceedings of the 17th Australian Poultry Science Symposium, February 7-9, 2005; Sydney, New South Wales, Australia. 17:227-228

Williams, M. P., B. Brown, S. Rao, and J. T. Lee. 2014. Evaluation of beta-mannanase and nonstarch polysaccharide-degrading enzyme inclusion separately or intermittently in reduced energy diets fed to male broilers on performance parameters and carcass yield. J. Appl. Poult. Res. 23:715-723.

Zanella, I., N. K. Sakomura, F. G. Silversides, A. Fiqueirdo, and M. Pack. 1999. Effect of enzyme supplementation of broiler diets based on corn and soybeans. Poult. Sci. 78:561-568.

Zou, X. T., X. J. Qiao, and Z. R. Xu. 2006. Effect of $\beta$-mannanase (Hemicell) on growth performance and immunity of broilers. Poult. Sci. 85:2176-2179. 